\title{
The Design of Accident Detection and Tracking Systems on Motorcycles
}

\author{
Febi Ramadaniati ${ }^{1}$, Suryadi $^{2},{ }^{*}$ Era Madona $^{3}$, Anton $^{4}$ \\ 1234 Jurusan Teknik Elektro Politeknik Negeri Padang, Jl. Limau Manih Padang, 25164, Indonesia \\ email:febiramadaniati16@gmail.com \\ *Corresponding Author: emadona38@gmail.com
}

\begin{abstract}
Motorcycles are type of vehicles with the highest accidents percentage every year. The location away from the settlement and the time of the accident is one of the factors that Slows down the spread of information about ccidents. This study aims to make a tool that can send such information in the form of notifications and crash site points to the families'victims. Testing was conducted by looking at the sensor response detecting tilt on the motorcycle against the large reading angle. Furthermore, GPS module accuracy testing is conducted in reading the location by comparing GPS module readings with actual location points in Google apps Maps which is then calculated by using the Haversine Formula method up to gsm module capability testing for send SMS notifications in the form of latitude, longitude, and links that can connect to the Google Maps app. Based on the results of the trials and analyses that have been conducted, the slope sensor response area to transmit crash notification is $\left\langle=50^{\circ}\right.$ or $>=50^{\circ}$. After that, the GSM module will send notifications and location points detected by the GPS module with an average reading difference of 2.97 meters.
\end{abstract}

Keywords: Tilt, Gps, Google_Maps

(C) 2021 Elektron Jurnal Ilmiah

\section{INTRODUCTION}

The lack of public awareness' discipline in traffic is due to the lack of knowledge of the Indonesian people about the importance of complying with applicable regulations and more concerned with the interests of individuals in using transportation facilities and infrastructure without thinking about the interests of others or the public interest [1]. Various efforts have been made to reduce the number of accidents such as regulations and signs and public service messages in the form of billboards and advertisements as a medium of conveying traffic safety messages. This safety message is often ignored so that it can be a factor in the cause of human error. Other factors that can cause accidents are vehiclefactor $(12.66 \%)$, road factor $(4.37 \%)$, and envir onmental factor $(3.06 \%)$ [2].

The hours of traffic accident can be distinguished into: (1) Early morning, starting from 00.00 - 06.00; (2) Morning, starting from $00.06-12.00$; (3) During the day, starting from $12.00-18.00$; (4) Night, starting from $18.00-24.00$ [3]. 00.00-06.00 is the time when people have been in their homes, if an accident occurred in that time and the location of the accident is far from residential, dissemination of information The accident will be too late. Therefore, a tool is needed that can transmit information and track the crash site.

Research relevant to Detection Systems Accidents are research conducted by Arie Suprayogi et al on "Detection Systems Accidents On Motorcycles Based Tilt Using Gyroscope Sensor Arduino-based". The results of the study obtained is an accident detection system that MPU6050 sensor as a detection motorcycle tilt with category $10^{\circ}-50^{\circ}$ for the left, $130^{\circ}-170^{\circ}$ for the right, and $60^{\circ}-120^{\circ}$ is declared as normal system or do not send messages [4].
The difference between this research and previous research was the addition of GPS as a location detector, where the family victims can track the crash site through link in SMS notification that can be connected directly to the Google Maps app and the addition of a button that serves to cancel the sending SMS if the motorcycle crashed accidentally or not included in the accident condition.

\section{METHOD}

This system was created using the MPU6050 module that utilizes measurement systems such as gyroscope and accelerometer for estimating relative position, speed, and acceleration of movement motor [5]. The Neo-7M GPS module is used to specify the locations with 5 types of reception (56 channels, GPS L1C/A, SBAS L1C/A, QZSS L1C/A, Galileo E1B/C) [6]. The accuracy of this GPS is about 2.5 meters [7]. Data results from sensors processed by Arduino Mega 2560 is opensource hardware [8]. All input and microcontroller are connected to Auto buck boost converter XL6009 which is connected to $5 \mathrm{~V}$ power from powerbank. The output of the system is a buzzer and GSM SIM 800C module for sending SMS controlled through the AT command [9]. SIM C800 using a serial TTL port so that it can be directly accessed using the microcontroller without max232[10]. Sending information via SMS more effective to use in every area especially in remote area that cannot access the internet.

The research phase began by designing and creating an electronic system consisting of MPU6050 sensor, U blox Neo-7 GPS, and push button as input. Arduino mega 2560 as a microcontroller. 800C SIM, mobile phone, and Google Maps application as output. Then 
continued with the manufacture of mechanical accident detection system.

The working principle of the system is shown in the diagram block figure 1 , based on the Arduino Mega 2560 microcontroller with three inputs namely MPU6050, Ublox Neo-7M GPS, and push button. The MPU6050 input is used as a tilt sensor that transmits data from channels $\mathrm{x}, \mathrm{y}$, and $\mathrm{z}$ with $\mathrm{I} 2 \mathrm{C}$ communication (SDA/SCL pins) to the Arduino Mega 2560. Then in the input navigation module Ublox Neo-7M will read the crash site (especially in the village cupak Tangah, district Pauh) by sending latitude and longitude data with serial communication (RX / TX) to Arduino Mega 2560. Then the push button input is used to cancel the process of sending SMS and phone calls by SIM800C by sending digital data worth 1 to Arduino Mega 2560. Push buttons can only be activated as long as the counter counts 1 time every 1 second for 10 seconds before sending SMS and phone calls. Each data submitted by each input will be processed by Arduino Mega2560.

The outputs on this system are buzzer, SIM800C, SMS notifications, and phone calls, as well as location display in the Google Maps app. Buzzer serves as an alarm that will activate when the MPU6050 detects the tilt of the motorcycle. If there is no push-button press, then SIM800C will send SMS (in the form of latitude coordinates, longitude, and links connected to the Google Maps application) and calls 08136753xxxx (victim's family number) 9 times. After that the Google Maps app can be accessed by clicking the link on the SMS notification.

The next stage of research is trials system as follows:

\section{1. MPU6050 tilt sensor testing}

MPU6050 uses I2C communication so it must be calibrated first using oscilloscope. Testing on the MPU6050 sensor consists of two parts, namely normal, tilted, and safe test conditions using a protractor and testing normal, tilted, safe conditions on motorcycles. The goal is to observe the tilt angle $\mathrm{x}, \mathrm{y}$, and $\mathrm{z}$ output values that appear under normal, tilted, and falling conditions in each rotation of the MPU6050 sensor. The tilt angle output of the MPU6050 sensor readings will be used as material to test the angle of normal, tilted, and falling conditions on the motorcycle.

\subsection{Ublox Neo-7M GPS Testing}

GPS module testing aims to determine how accurately the location coordinate readings captured by GPS satellites using the Ublox Neo-7M module and calculate the difference between latitude and longitude points using the Neo-7M GPS module with coordinate values obtained from the Google Maps app.

\subsection{Alarm Circuit Testing}

The purpose is to test the buzzer circuit as an active alarm when theMPU6050 module detects tilt and fall conditions on tilt angle $X$ with values $<=-7.38 \mathrm{~m} / \mathrm{s}^{2}$ and $>=7.48 \mathrm{~m} / \mathrm{s}^{2}$.

\subsection{GSM SIM800C Module Testing}

The goal is to test the gsm module's ability to send SMS and make phone calls to the victim's family number (08126753xxxx) based on oblique and falling conditions.

\subsection{Delivery Revocation Circuit Testing}

This series is made with a button as an emergency button to cancel SMS and phone calls when the motorcycle falls accidentally or does not include accident.

\section{RESULTS AND DISCUSSION}

Figure 2 shows an electronic system that has been integrated with the Arduino Mega2560 microcontroller. The system works at 5VDC voltage with powerbank as voltage supply. The voltage of the powerbank is paralleled to each auto buck-boost converter so that each component gets an input voltage according to its working voltage. For push button and buzzer can take voltage input directly from arduino.

\subsection{MPU6050 Test Result}

\section{A. Condition Testing Using Protractor}

In table 1 tilt angel output the MPU6050 module can be both positive and negative in accordance with the position/position/placement of the sensor itself.

The value at tilt angle $\mathrm{x}$ is positive when the rotation is clockwise and negative when rotated counterclockwise Tilt angle $\mathrm{x}$ and $\mathrm{y}$ values can be observed changing in value when the sensor is placed in an upright position. 


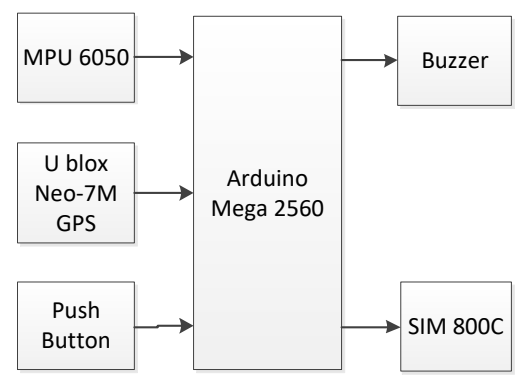

\begin{tabular}{|c|}
\hline Handphone \\
\hline $\begin{array}{c}\text { SMS ( } \\
\text { latitude,longitude } \\
\text { data and link) \& call } \\
\text { phone }\end{array}$ \\
\hline Google Maps Apps \\
\hline
\end{tabular}

Figure 1. Block diagram system

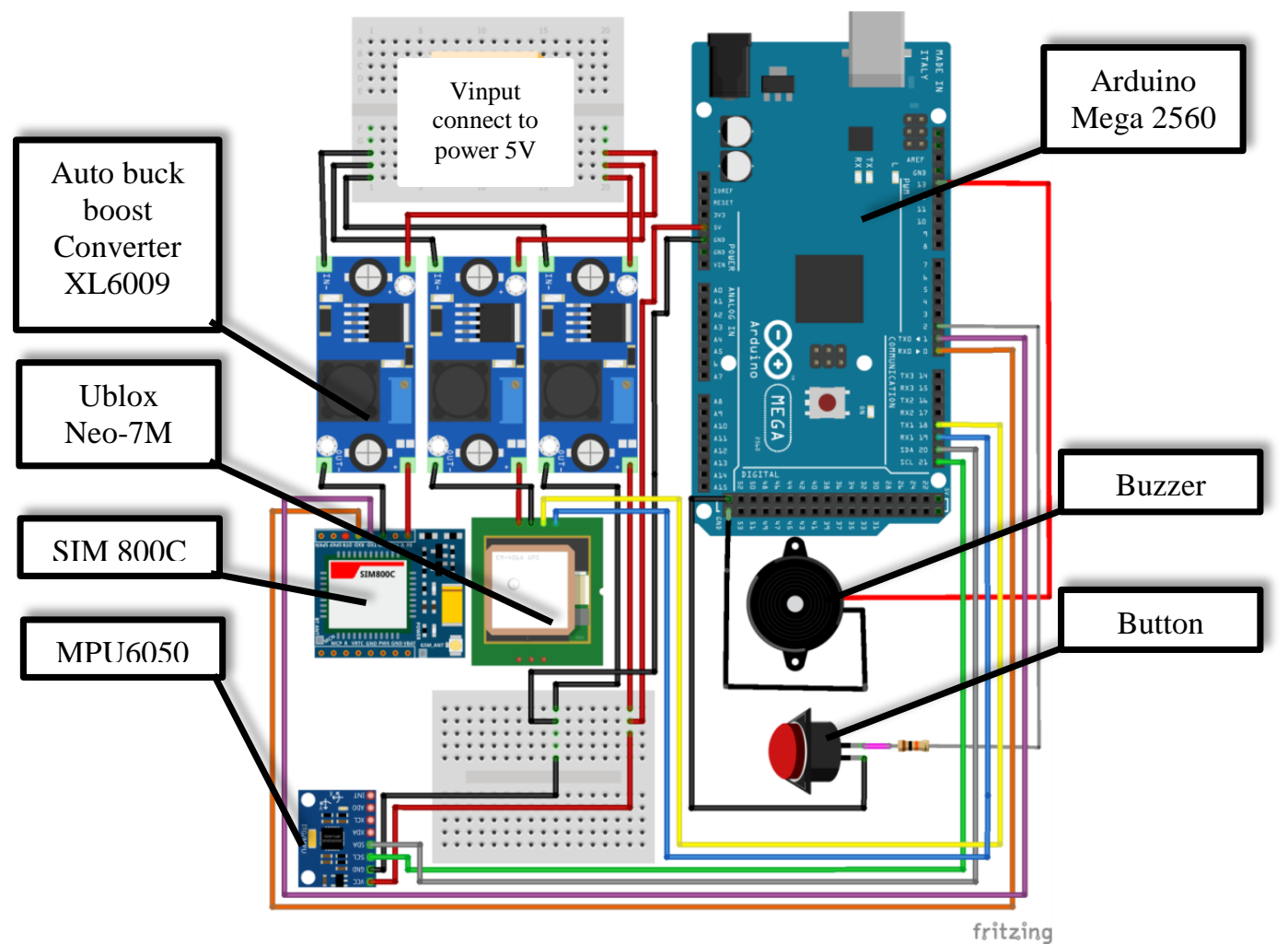

Figure 2. The entire electronic network system

Table 1. Output tilt angel $\mathrm{x}, \mathrm{y}$,and $\mathrm{z}$ on the protractor test

\begin{tabular}{|c|c|c|c|c|c|c|c|c|}
\hline \multirow{2}{*}{ Angle } & \multirow{2}{*}{$\begin{array}{c}\text { Tilt } \\
\text { angle }\end{array}$} & \multicolumn{5}{|c|}{ Experiment } & \multirow{2}{*}{ Average } & \multirow{2}{*}{$\begin{array}{l}\text { Standard } \\
\text { deviation }\end{array}$} \\
\hline & & 1 & 2 & 3 & 4 & 5 & & \\
\hline \multirow{3}{*}{-90} & $\mathrm{x}$ & $-9,64$ & $-9,68$ & $-9,71$ & $-9,70$ & $-9,71$ & $-9,69$ & 0,03 \\
\hline & $\mathrm{y}$ & $-0,41$ & $-0,51$ & 0,21 & 0,16 & 0,02 & $-0,11$ & 0,33 \\
\hline & $\mathrm{z}$ & 1,40 & 1,33 & 1,45 & 1,24 & 1,40 & 1,36 & 0,08 \\
\hline \multirow{3}{*}{-50} & $\mathrm{x}$ & $-7,40$ & $-7,40$ & $-7,37$ & $-7,45$ & $-7,39$ & $-7,38$ & 0,03 \\
\hline & $\mathrm{y}$ & $-6,40$ & $-6,36$ & $-6,43$ & $-6,32$ & $-6,37$ & $-6,38$ & 0,04 \\
\hline & $\mathrm{z}$ & 1,05 & 1,59 & 1,64 & 1,42 & 1,53 & 1,45 & 0,24 \\
\hline \multirow{2}{*}{0} & $\mathrm{x}$ & 0,06 & 0,22 & 0,05 & 0,01 & 0,02 & 0,07 & 0,09 \\
\hline & $\mathrm{y}$ & $-9,85$ & $-9,83$ & $-9,85$ & $-9,86$ & $-9,85$ & $-9,85$ & 0,01 \\
\hline
\end{tabular}




\begin{tabular}{|c|c|c|c|c|c|c|c|c|}
\hline & $\mathrm{z}$ & 1,28 & 1,22 & 1,18 & 1,28 & 1,24 & 1,24 & 0,04 \\
\hline \multirow{3}{*}{50} & $\mathrm{x}$ & 7,64 & 7,41 & 7,33 & 7,59 & 7,47 & 7,40 & 0,13 \\
\hline & $\mathrm{y}$ & $-6,31$ & $-6,52$ & $-6,63$ & $-6,35$ & $-6,47$ & $-6,46$ & 0,13 \\
\hline & $\mathrm{z}$ & 1,02 & 1,37 & 1,29 & 1,39 & 1,19 & 1,25 & 0,15 \\
\hline \multirow{7}{*}{90} & $\mathrm{x}$ & 9,86 & 9,86 & 9,84 & 9,82 & 9,87 & 9,85 & 0,02 \\
\hline & $\mathrm{y}$ & $-0,52$ & $-0,23$ & $-0,77$ & $-0,15$ & $-0,35$ & $-0,40$ & 0,25 \\
\hline & $\mathrm{z}$ & 1,07 & 1,14 & 1,13 & 0,75 & 1,30 & 1,08 & 0,20 \\
\hline & & & & & & Average & $-1,10$ & 0,12 \\
\hline & & & & & & \multicolumn{2}{|c|}{ Absolute error } & 0,03 \\
\hline & & & & & & \multicolumn{2}{|c|}{ Ralative error } & $-3 \%$ \\
\hline & & & & & & \multicolumn{2}{|c|}{ Accuracy } & $97 \%$ \\
\hline
\end{tabular}

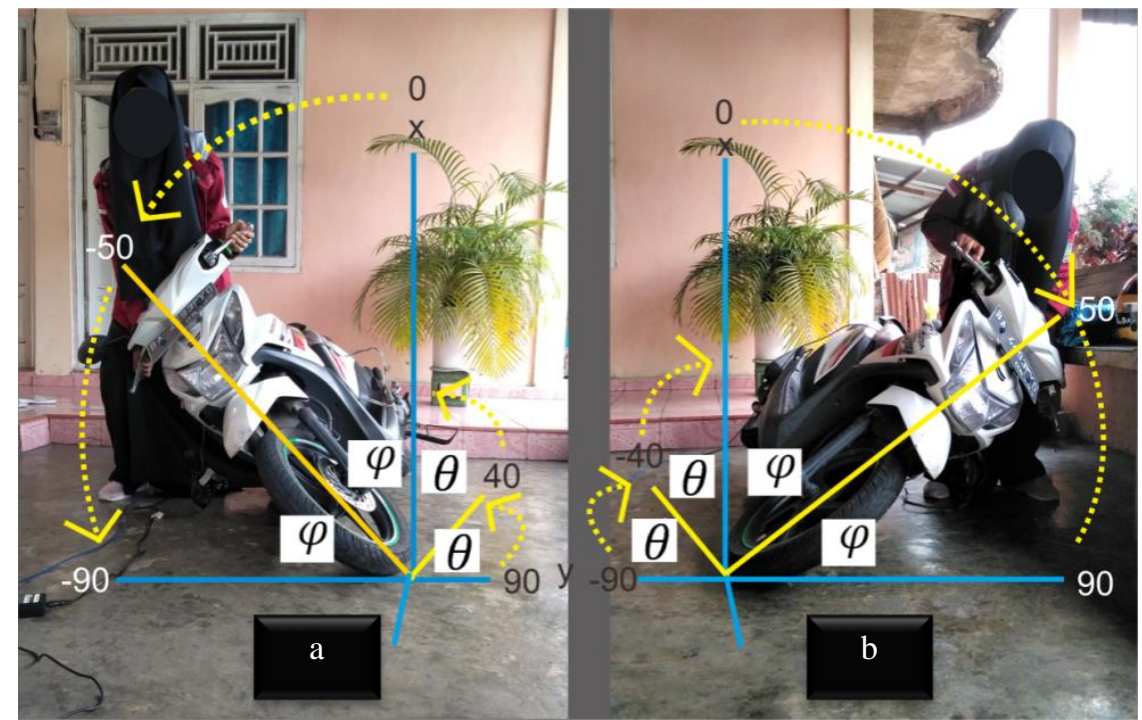

Figure 3 (a), (b) Testing the condition of a motorcycle

B. Testing of normal, tilted, and falling conditions on a motorcycle

In figure 3 (a) is the right tilt condition on motorcycles based on changes in the $\mathrm{x}, \mathrm{y}$, and $\mathrm{z}(\varphi, \theta$, and $\psi$ axes), where when the angle of $\varphi 0^{\circ}$ to $>-50^{\circ}$ and an angle of $90^{\circ}$ to $>40^{\circ}$ are normal conditions, $-50^{\circ}$ is an oblique condition, and $<-50^{\circ}$ to $-90^{\circ}$ is a fall condition. while figure 3 (b) is the condition of the left tilt motor, where when the angle of $\varphi 0^{\circ}$ to $<50^{\circ}$ is the normal condition, the angle of $50^{\circ}$ is the oblique condition, and the angle of $>50^{\circ}$ to $90^{\circ}$ is the fall condition.

Based on figure 3, the comparison of angle change values with tilt angle values $\mathrm{x}, \mathrm{y}$, and $\mathrm{z}$ can be seen in table 2 . In table 2 , in normal conditions the value of phi $/ \varphi$ is $0->-50$, meaning that the value of phi in normal conditions is from point $0^{\circ}$ to greater than $-50^{\circ}$. Tilt angle $x$ value in tilt and fall condition will be the reference as the value that will be inserted in the program at once as a buzzer trigger and make SMS and phone calls. The $\mathrm{x}$ tilt angle values in the program are $<=-7.38 \mathrm{~m} / \mathrm{s}^{2}$ and $>=7.48 \mathrm{~m} / \mathrm{s}^{2}$. 
Table 2. Comparison of the angle value and the tilt angel output value

\begin{tabular}{|c|c|c|c|c|c|c|}
\hline \multirow{2}{*}{ Condition } & \multicolumn{3}{|c|}{ Angle Value $\left(^{\circ}\right)$} & & \multicolumn{2}{|c|}{ Output tilt angle $\left(\mathrm{m} / \mathrm{s}^{2}\right)$} \\
\hline & & Right & Left & & Right & Left \\
\hline \multirow{3}{*}{ Normal } & $\varphi$ & $0->-50$ & $0-<50$ & $\mathbf{x}$ & $0,23->-7,38$ & $0,23-<7,48$ \\
\hline & $\boldsymbol{\theta}$ & $90->40$ & $-90-<40$ & $\mathbf{y}$ & $-9,69-<-6,39$ & $-9,69--6,46$ \\
\hline & $\psi$ & 0 & 0 & $\mathbf{z}$ & $1,23-<1,47$ & $1,23-<1,34$ \\
\hline \multirow{3}{*}{ Tilted } & $\varphi$ & -50 & 50 & $\mathbf{x}$ & $-7,38$ & 7,48 \\
\hline & $\theta$ & 40 & -40 & $\mathbf{y}$ & $-6,39$ & $-6,46$ \\
\hline & $\psi$ & 0 & 0 & $\mathbf{z}$ & 1,47 & 1,34 \\
\hline \multirow{3}{*}{ Fall } & $\varphi$ & $<-50--90$ & $>50-90$ & $\mathbf{x}$ & $<-7,38--9,72$ & $>7,48-9,64$ \\
\hline & $\boldsymbol{\theta}$ & $<40-0$ & $>-40-0$ & $\mathbf{y}$ & $>-6,39--0,27$ & $>-6,46--0,42$ \\
\hline & $\psi$ & 0 & 0 & $\mathbf{z}$ & $>1,47-1,42$ & $>1,34-1,12$ \\
\hline
\end{tabular}

\subsection{GPS Test Result}

The coordinates of the test position are -0.927869 , 100.433592. These coordinate points are retrieved by utilizing the Google Maps app based on their real location and position. Gps module readings will be compared to the actual position coordinates using the Haversine formula method [11]..

$d=2 r \sin ^{-1}\left(\sqrt{\sin ^{2}\left(\frac{\Delta \varphi}{2}\right)+\cos (\varphi 1) \cos (\varphi 2) \sin ^{2}\left(\frac{\Delta \lambda}{2}\right)}\right)$

Description:

$\mathrm{d}$ : distance

$\varphi$ : latitude

$\lambda$ : longitude

$\mathrm{r}$ : earth radius (radius mean $=6,371 \mathrm{~km}$ )

Equation (1) will extract into excel to make it easier to see the comparison of data obtained from the test results such as figure 4 Following:

\begin{tabular}{|c|r|r|r|r|r|}
\hline no & Latitude1 & Longitude1 & Latitude2 & Longitude2 & Distance (Meter) \\
\cline { 2 - 6 } & $-0,927869$ & 100,433592 & $-0,927845$ & 100,433620 & 4,100352863 \\
\hline
\end{tabular}

Figure 4. Comparison of data in Excel 1st experiment

Based on figure 4 in the first test, the GPS module can read the coordinates of the location close to the actual test point with a difference of \pm 4 meters if left on a condition a few minutes after the module obtains a GPS signal.

\subsection{Alarm circuit test results}

Buzzer serves as the output of the system that will only be active when the tilt angle $\mathrm{x}$ output is $<=-7.38$ and $>=7.48$ with a voltage of $5 \mathrm{~V}$ when active and a voltage of $0 \mathrm{~V}$ when motor conditions are normal.

\subsection{GSM module test results}

In the GSM SIM800C module test, SMS and phone calls will be sent to the number set on the device based on the tilt angle $x$ value at the tilt and fall conditions of $<=-7.38$ or $>=7.48$ with an angle of $<-50^{\circ}$ or $>50^{\circ}$. The high input on the button serves as a cancellation of SMS sending and phone calls. From the test results of SMS delivery and phone calls it is known that SMS sending and phone calls can be done depending on the availability and signal strength of the GSM card used. Modules can send SMS with AT+CMGS commands and make phone calls with ATD commands.

3.5 Test results of delivery limit series SMS and phone calls

Button will be low when it is pressed $(b=1)$. This can happen because in the circuit of push button added by pull up resistors of $10 \mathrm{k} \Omega$ thus when there is no button press, the current will flow between VCC and the input pin in a small amount so that the pin read approach to VCC and read high. Then if there is a button press then the input pin will be connected to the ground which causes the input pin to read low. To be able to know the success of the work of the tool /system then conducted testing directly by placing the tool on the motor and testing the tilt sensor until the delivery/cancellation of phone calls and SMS delivery. 


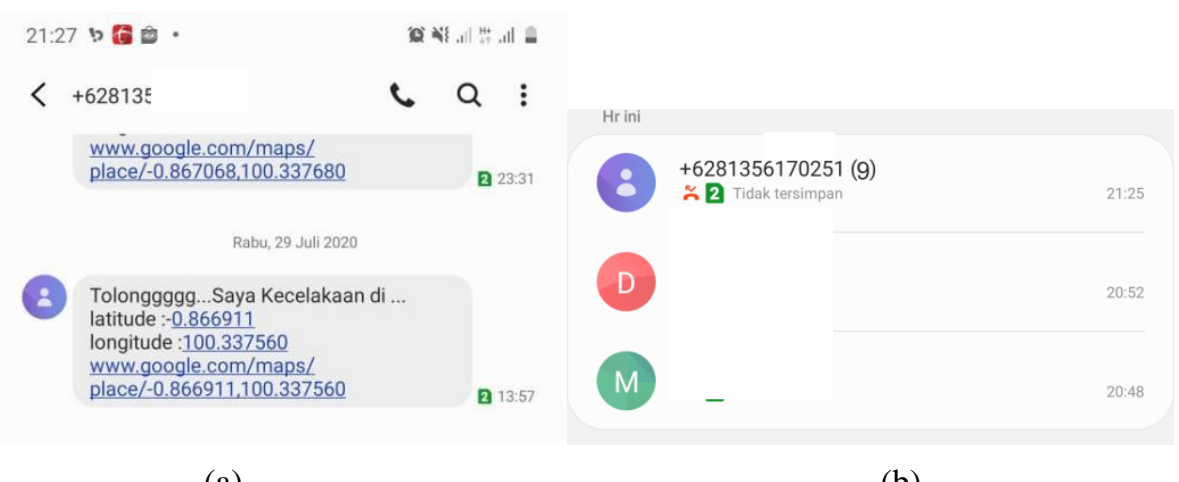

(a)

(b)

Gambar 5 (a), (b). SMS alerts \& phone calls on numbers that are far from the test site

In figure 5 (a) is the format resulting from the reading of the GPS module, and figure 5 (b) is the history of phone calls by the GSM SIM800C module made 9 times.
The linking in figure 5(a) will be display the Google maps application view as shown in the following figure 6. Thus, the victim's family can track the whereabouts of the accident victim through a link sent to the SMS

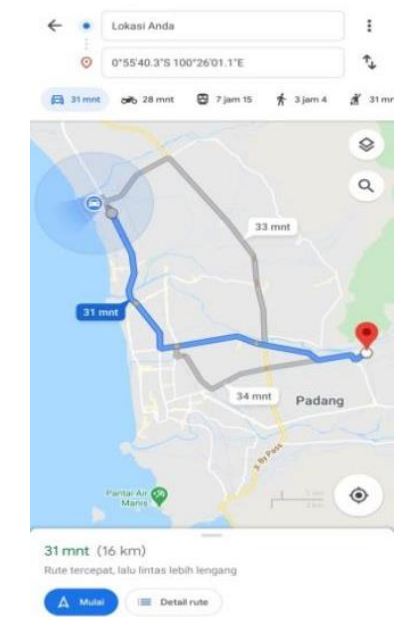

Figure 6. Position tracking of SMS link sending that are far from the test site

\section{CONCLUSION}

After testing and retrieving data on the tool directly, it can be concluded as follows. Tests on the tilt sensor show that the appliance can send SMS and phone calls at $<-50^{\circ}$ and $>50^{\circ}$ angles with a tilt angle value of $\mathrm{x}<=-7.38$ and $\mathrm{x}>=7.48$ in tilt and fall conditions with a module reading accuracy of $97 \%$, error of 0.03 . The test results of the navigation module show that the GPS module can determine the location by shifting the reading position of the GPS module to the test point with a difference of \pm 4 meters on the 1 st test data.

\section{REFERENCE}

[1] Utomo Nugroho, “ANALISA FAKTOR PENYEBAB KECELAKAAN LALU LINTAS PADA SEGMEN JALAN BYPASS KRIAN - BALONGBENDO," vol. 2, no. 2, pp. 73-84, 2012.

[2] A. Fajar Wibisono and F. Bamardi, "Penyuluhan Pentingnya Kesadaran Diri Dalam Berlalu Lintas Sesuai Aturan hukum yang Berlaku di Dusun Deles," vol. 3, no. 1, pp. 1- 5, 2014.

[3] A. A. Anisarida and W. Santosa, "Korban Kecelakaan Lalu Lintas Sepeda Motor Di Kota Bandung," J. HPJI, vol. 5, no. 2, pp. 129-136, 2019, doi: 10.26593/jh.v5i2.3373.129-136.

[4] A. Suprayogi and H. Fitriyah, "Sistem 
Pendeteksi Kecelakaan Pada Sepeda Motor Berdasarkan Kemiringan Menggunakan Sensor Gyroscope Berbasis Arduino," vol. 3, no. 3, pp. 3079-3085, 2019.

[5] B. Firman, "IMPLEMENTASI SENSOR IMU MPU6050 BERBASIS SERIAL I2C PADA SELF-BALANCING ROBOT Vol . 9 No . 1 Agustus 2016 ISSN : 1979-8415," Juenal Teknol. Technoscientia, vol. 9, no. 1, pp. 18-24, 2016.

[6] A. R. H. Martawireja and H. Supriyanto, "Penentuan Lintasan Pergerakan Quadcopter Berbasis GPS (Global Positioning System)," J. Teknol. dan Rekayasa Manufaktur, vol. 1, no. 2, pp. 114, 2019, doi: 10.48182/jtrm.v1i2.7.

[7] R. Handayani, M. I. Sari, A. A. G. Agung , F. Ramdana, and A. Wahyudi, "Alert, monitoring and tracking for electronic device prototype", proceeding $201711^{\text {th }}$ Int. Conf. Telecommun. Syst. Serv. Appl. TSSA 2017, vol. 2018-january, pp. 1-4, 2018.

[8] J. Arifin, L. N. Zulita, and Hermawansyah, "Perancangan Murottal Otomatis Menggunakan Mikrokontroller Arduino Mega 2560," J. Media Infotama, vol. 12, no. 1, pp. 89-98, 2016, [Online]. Available: https://jurnal.unived.ac.id/index.php/jmi/art icle/view/276/257.

[9] A. Nugraha, "Sistem Keamanan Sepeda Motor Menggunakan Arduino Berbasis Android," Fatmah Riski Dinniah, vol. 2, no. 1, pp. 1-16, 2017.

[10] D. Andesta and R. Ferdian, "Sistem Keamanan Sepeda Motor Berbasis Mikrokontroler dan Modul GSM," J. Inf. Technol. Comput. Eng., vol. 2, no. 02, pp. 51-63, 2018, doi: 10.25077/jitce.2.02.5163.2018.

[11] R. Putra and H. Sujiani, "Penerapan Metode Haversine Formula Pada Sistem Informasi Geografis Pengukuran Luas Tanah," vol. 10, no.1, pp. 1262-1270, 2015. 